\title{
ATYPICAL ADULT-ONSET SUBACUTE SCLEROSING PANENCEPHALITIS
}

\author{
Lorna Stemberger Marići ${ }^{1}$ Oktavija Đaković Rode ${ }^{2}$, Klaudija Višković ${ }^{3}$, \\ Hrvoje Hećimović ${ }^{4}$, Smiljka Lambaša ${ }^{5}$ and Dragan Lepur ${ }^{6}$
}

\begin{abstract}
${ }^{1}$ School of Dental Medicine, University of Zagreb, Dr Fran Mihaljević University Hospital for Infectious Diseases, Zagreb, Croatia;

${ }^{2}$ School of Dental Medicine, University of Zagreb, Department of Microbiology,

Dr Fran Mihaljević University Hospital for Infectious Diseases, Zagreb, Croatia;

${ }^{3}$ Department of Radiology, Dr Fran Mihaljević University Hospital for Infectious Diseases, Zagreb, Croatia;

${ }^{4}$ Department of Neurology, Sestre milosrdnice University Hospital Centre, Zagreb, Croatia;

${ }^{5}$ Department of Pathology, Dubrava University Hospital, Zagreb, Croatia;

${ }^{6}$ School of Dental Medicine, University of Zagreb, Department of Intensive Care Medicine and Neuroinfectology,

Dr Fran Mihaljević University Hospital for Infectious Diseases, Zagreb, Croatia
\end{abstract}

\begin{abstract}
SUMMARY - Although subacute sclerosing panencephalitis is almost exclusively a childhood disease, it can occur in adults as well. We present an atypical case of adult-onset subacute sclerosing panencephalitis. The disease was characterized by prolonged insidious course followed by accelerated and aggressive phase, atypical EEG findings, and absence of myoclonic jerks. The diagnostic and treatment-related pitfalls are discussed.
\end{abstract}

Key words: Adult onset; $M R Z$ (measles, rubella, varicella-zoster) reaction; Multiple sclerosis; Subacute sclerosing panencephalitis

\section{Introduction}

Subacute sclerosing panencephalitis (SSPE) is traditionally described as a devastating childhood and early adolescence disease caused by persistent mutated measles virus. The diagnosis is based on characteristic clinical presentation, electroencephalographic (EEG) findings and increased antibody titer to measles both in serum and cerebrospinal fluid $(\mathrm{CSF})^{1}$. However, the majority of patients (78.8\%) are initially incorrectly diagnosed even in developing countries with a high annual incidence of SSPE (up to 21 cases per million in general population) $)^{2}$. The diagnosis of adult-onset SSPE, particularly in those patients with insidious

Correspondence to: Dragan Lepur, $M D, P h D$, Department of Intensive Care Medicine and Neuroinfectology, Dr Fran Mihaljević University Hospital for Infectious Diseases, Mirogojska 8, HR10000 Zagreb, Croatia

E-mail: dragan.lepur@xnet.hr

Received April 13,2016, accepted December 8, 2016 course of the disease, can be quite challenging ${ }^{3,4}$. We present an atypical case of adult-onset SSPE and detailed discussion of diagnostic and treatment-related pitfalls.

\section{Case Report}

A 42-year-old Caucasian male with suspected Creutzfeldt-Jakob disease was transferred to our Hospital from the Department of Neurology in October 2011. He was born in 1969 in an urban community in Croatia and had been vaccinated according to the national immunization schedule that included measles vaccine. Measles vaccination was introduced to the Croatian mandatory immunization program in 1968. His past medical history was unremarkable. There was no history of fever, arthritis, arthralgias, myalgias or rash. In addition, there were no recent measles epidemics recorded in Croatia. 
The disease had started two years before hospitalization with bilateral decreased visual acuity attributed to optic neuropathy and macular dystrophy followed by depression. Magnetic resonance imaging (MRI) of
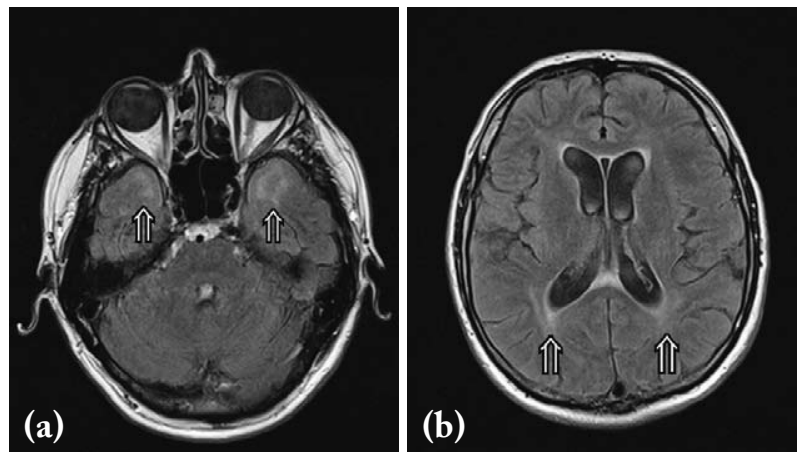

Fig. 1. Axial fluid attenuation inversion recovery (FLAIR) sequence of the brain: (a) byperintensity in subcortical gray matter of temporal lobes; and (b) in periventricular white matter (arrows) with diffuse brain atrophy.
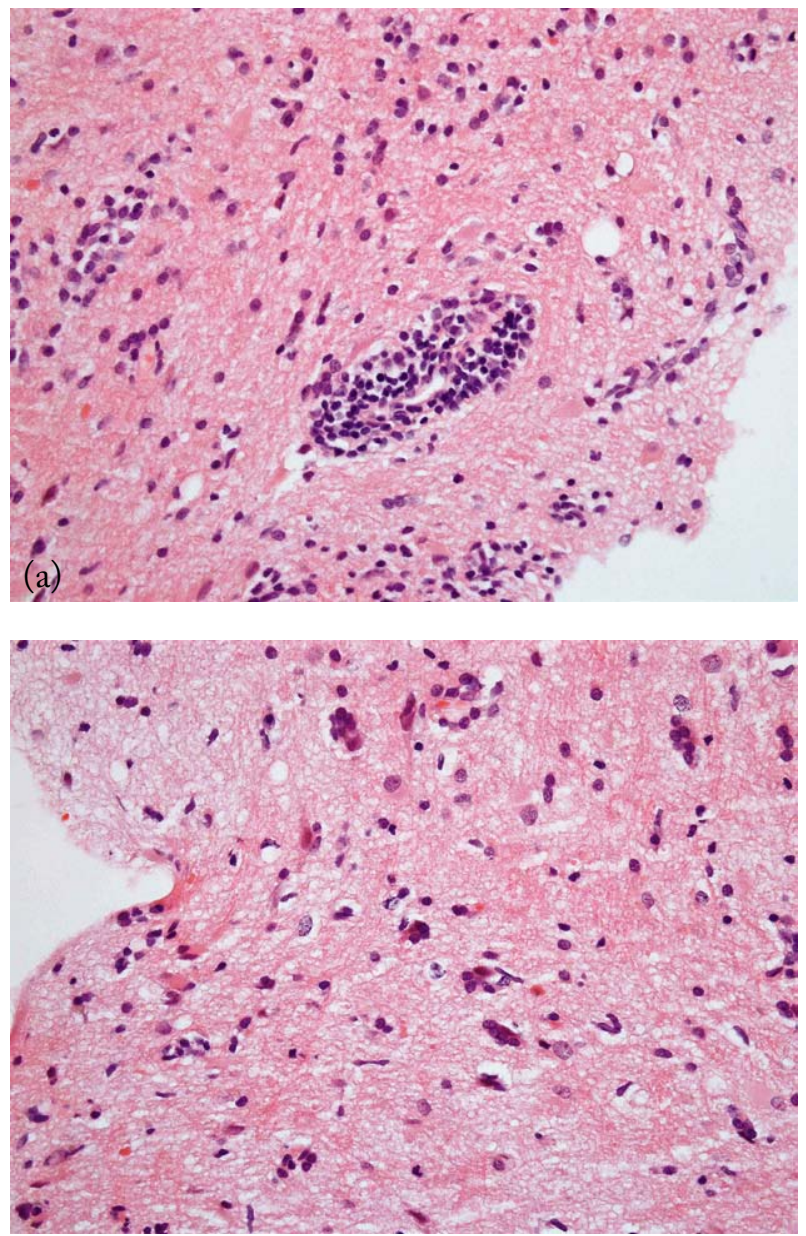

the brain in 2009 showed demyelination changes (details unknown). He was taking drugs prescribed by a psychiatrist (alprazolam and paroxetine). Eighteen months later, he developed left-sided hemiparesis and was hospitalized in June 2011. The initial MRI of the brain performed on a $1.5 \mathrm{~T}$ unit revealed symmetric, scattered, high signal intensity areas on T2 weighted image (WI) and fluid attenuation inversion recovery (FLAIR) sequence in the periventricular white matter, as well as in the frontal and temporal subcortical gray matter (Fig. 1). There was no enhancement on postcontrast T1 WI. Diffuse brain atrophy was present. Lumbar puncture revealed 1 cell per cubic millimeter, glucose level of $4.3 \mathrm{mmol} / \mathrm{L}$ and total protein level of $0.64 \mathrm{~g} / \mathrm{L}$. The function of the blood-brain barrier (BBB) was normal with intrathecal synthesis of $\mathrm{IgG}$. Oligoclonal IgG bands (OCB) were found in CSF with additional identical bands in CSF and serum (OCB type 3). In order to detect polyspecific intrathecal antibody response to neurotropic viruses, the so-

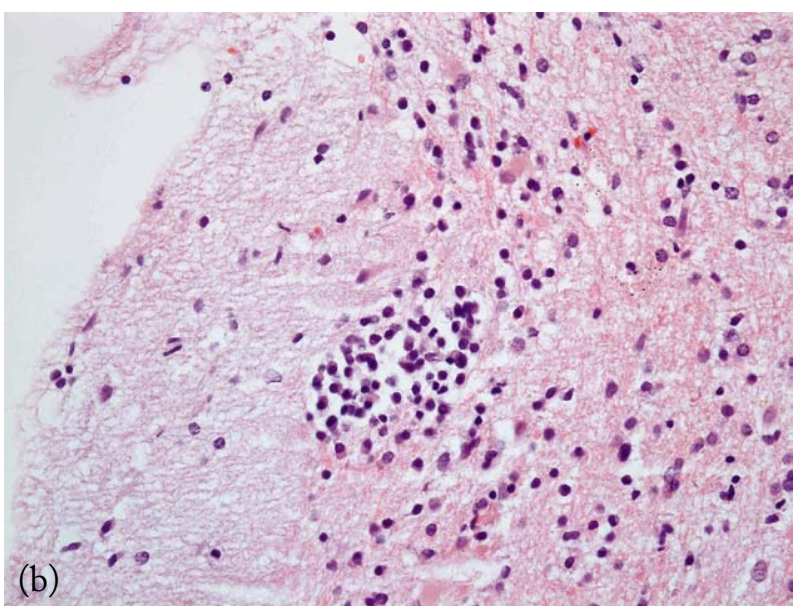

Fig. 2. Histopathologic examination revealed perivascular inflitration of T-lymphocytes (hemalauneosin, X20) (a); microglial nodules, reactive astrogliosis (hemalaun-eosin, X40) (b); and neuronophagia, marked with asterisks (hemalaun-eosin, X40) (c), compatible with viral encephalitis. 


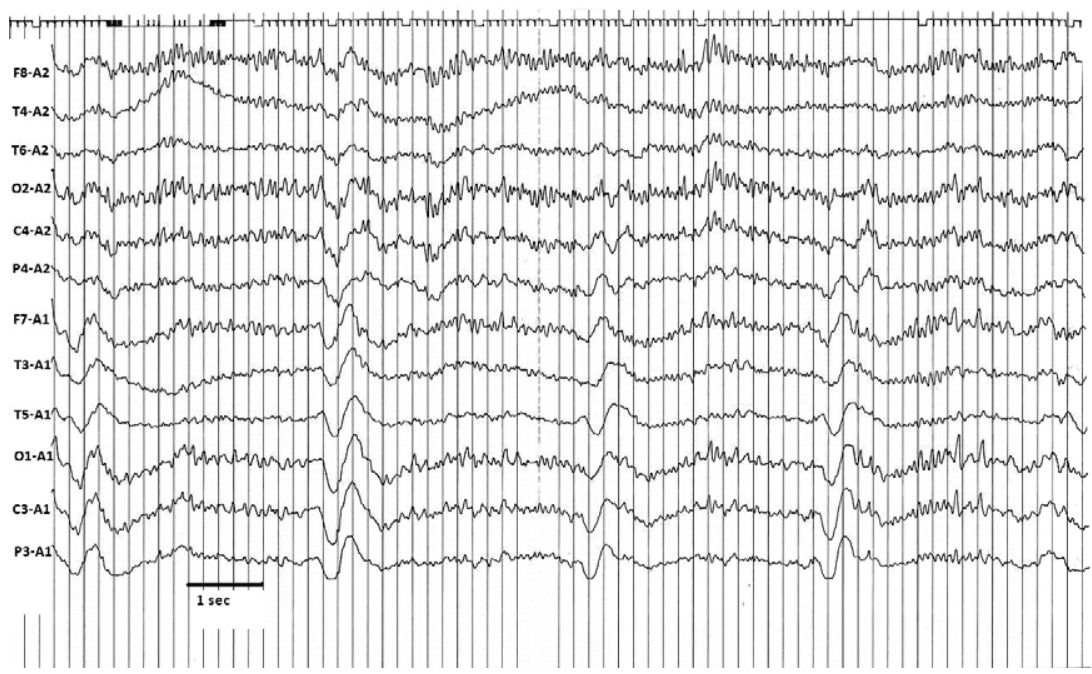

Fig. 3. Electroencephalography showing periodic biphasic and triphasic delta wave discharges bilaterally and synchronously, larger in amplitude over the left temporo-occipital region, occurring at intervals of 3-4s.

called MRZ (measles, rubella, varicella-zoster) reaction revealed positive antibody index (AI 6.2) for measles but negative for rubella (AI 0.6), varicellazoster (AI 0.6) and herpes simplex virus (AI 0.9). EEG was normal. Visual evoked response (VER) revealed a mild right-sided delay in conduction at the pre-chiasmatic level. Brainstem auditory evoked response (BAER) revealed a right-sided delay in conduction at the brainstem level.

Despite nonspecific MRI findings and unusual OCB pattern, the diagnosis of probable multiple sclerosis (MS) was made and the patient was started on a high dose of methylprednisolone with certain clinical improvement. Two weeks later, his condition progressively aggravated with severe cognitive decline accompanied by increased fatigue, lethargy, pyramidal and extrapyramidal signs, but without myoclonic jerks. Follow-up MRI examination performed one month after the initial one was described as progression of hyperintensity lesions on T2 WI and FLAIR sequences in subcortical temporal, occipital and parietal lobes, bilaterally and symmetrically, without enhancement on postcontrast T1 WI. The radiological differential diagnosis included MS, acute disseminated encephalomyelitis and finally posterior reversible leukoencephalopathy. However, the substantial progress of initially described MRI changes was not confirmed by other MRI experts during the revision process.
The patient was consecutively treated with a high dose of steroids (methylprednisolone), intravenous immunoglobulins and finally plasmapheresis (total plasma exchange, TPE). All these treatments turned out to be completely ineffective.

The extensive diagnostic workup including autoimmune, metabolic and endocrine screening was negative. Funduscopy revealed chorioretinal degeneration on the right eye and decolorized optic papilla on the left eye. After consulting infectious disease specialists, additional tests were conducted. Treponema pallidum hemagglutination assay was negative. Tests for antibodies to measles, HIV 1 and 2, Mycoplasma pneumoniae and Borrelia burgdorferi were also negative. Protein 14-3-3 in CSF was positive and the patient was ultimately transferred to our Department.

Repeated lumbar puncture revealed 2 cells per cubic millimeter, glucose level of $3.5 \mathrm{mmol} / \mathrm{L}$ and total protein level of $1.0 \mathrm{~g} / \mathrm{L}$. The BBB dysfunction with intrathecal synthesis of IgG was found. CSF concentration of neuron-specific enolase was $7.6 \mu \mathrm{g} / \mathrm{L}$ (nor$\mathrm{mal}<15.5 \mu \mathrm{g} / \mathrm{L}$ ), protein Tau $505 \mathrm{pg} / \mathrm{mL}$ (normal $<150 \mathrm{pg} / \mathrm{mL}$ ) and $\mathrm{S}-1004.05 \mu \mathrm{g} / \mathrm{L}$ (normal $<2.5$ $\mu \mathrm{g} / \mathrm{L})$. Polymerase chain reaction (PCR) of CSF for JC virus, human herpesvirus 6, Epstein-Barr virus, cytomegalovirus and measles virus was negative. The EEG taken on admission showed pseudoperiodic biphasic and triphasic delta waves over the left temporo- 
occipital region with irregular background rhythm. Finally, brain biopsy was performed due to the progressive course of the disease, the possibility of primary CNS angiitis, and nonspecific and inconclusive previous diagnostic tests. Unfortunately, PCR for measles virus detection from brain tissue was not done because of inadequate sample. Histopathologic examination revealed perivascular infiltration of T-lymphocytes, microglial nodules, neuronophagia and astrogliosis compatible with viral encephalitis (Fig. 2).

Four weeks later, repeated EEG showed periodic high-amplitude biphasic and triphasic delta wave discharges bilaterally and synchronously, larger in amplitude over the left temporo-occipital region, occurring at intervals of 3-4 s (Fig. 3). Because of that, the diagnosis of SSPE was reconsidered and measles antibodies testing was repeated in the serum and CSF with enzyme immunoassay (Measles Virus IgG/IgM SERION ELIA classic Institut Virion/Serion $\mathrm{GmbH}$, Leipzig, Germany) according to the manufacturer's instructions. Serum and CSF anti-measles IgG antibodies titers were $>5000 \mathrm{IU} / \mathrm{L}$ and $>5000 \mathrm{IU} / \mathrm{L}$, respectively (positive IgG >200 IU/L). The calculated CSF IgG antibody index was 28.3 indicating intrathecal synthesis of measles IgG. SSPE was definitely diagnosed and the patient was transferred to the county hospital where he died two and a half years after the initial onset of symptoms.

\section{Discussion}

We have described a case of an unusual form of SSPE in an adult patient characterized by atypical EEG findings and absence of myoclonic jerks. In spite of numerous diagnostic pitfalls, he ultimately met diagnostic criteria for SSPE. The possibility of Creutzfeldt-Jakob disease was immediately discarded at admission to our Department because of the long period between visual impairment and cognitive dysfunction, as well as the absence of myoclonic jerks, typical EEG and MRI findings. Positive 14-3-3, Tau and $\mathrm{S}-100$ proteins in the CSF indicated severe but not specific neuronal damage.

After careful revision of his medical history, we recognized several misleading factors. Above all, it was an insidious course of disease which started with visual disturbance and depression syndrome for 18 months. The new-onset motor symptoms with initial MRI findings suggested a relapse of MS. The history of optic neuropathy, VER and BAER findings, positive $\mathrm{OCB}$, together with certain improvements after steroid treatment, supported the clinical diagnosis. However, the unfavorable disease course despite the immunosuppressive treatment with a lack of evidence for infectious disease supported the idea of primary CNS vasculitis refractory to steroids.

Common MRI findings in patients with SSPE are cortical and subcortical asymmetric hyperintense lesions on T2 WI in the posterior brain regions. Basal ganglia are usually affected after the cortex. However, MRI can be normal or may show asymmetric changes in the early stages of the disease, and changes do not always correlate with the clinical stage ${ }^{5,6}$. With the disease progression, the lesions may disappear and new lesions may occur symmetrically in the periventricular white matter, associated with cortical atrophy ${ }^{7}$. In our patient, the initial MRI finding available showed signs of already advanced disease, which is difficult to distinguish from a wide spectrum of other white matter diseases including acute disseminated encephalomyelitis, acute viral encephalitis, MS and metabolic white matter disease. Taking in consideration the revised and modified McDonald's criteria for MS, it was not possible to exclude MS based only on imaging criteria ${ }^{8}$.

The antibody indices of specific IgG antibodies, the so-called MRZ reaction (MRZR) was recently introduced to the methods used to diagnose MS. MRZR reflects the intrathecal synthesis of specific IgG antibodies to measles $(M)$, rubella $(R)$ and varicella-zoster $(Z)$ viruses. MRZR was shown to be a valuable paraclinical examination tool, detectable in CSF of 80\%$100 \%$ of MS patients and more specific compared to $\mathrm{OCB}^{9}$. However, careful assessment of MRZR is advised, particularly in cases where it is positive for only one virus and associated with $\mathrm{OCB}$ type 3 . When MRZR score does not surpass the cut-off value of 10 (if antibody index is positive: 9 points for measles, 8 points for rubella and 1 point for varicella-zoster virus), as it was in this patient, then chronic viral encephalitis including SSPE should be taken in consideration. According to the literature, the antibody indices for measles in patients with definitive SSPE were found to be in a range of 2.3-36.9 (mean 12.9) ${ }^{10}$. Because MRZR has been considered as a substantial contribution to the diagnosis of MS, it represented a confounding factor in this case. Furthermore, the slow 
forms of SSPE with initial visual manifestations that may precede other neurological signs by several years, as well as depression syndrome have been previously reported $^{11-14}$.

Not only delayed, but also atypical EEG findings considerably affected the diagnostic procedure. The first EEG changes, which provoked suspicion of SSPE, were seen as late as 5 months after the onset of the accelerated phase (one month before definitive diagnosis). Atypical EEG findings in SSPE are very rare, regardless of the course of the disease or patient age ${ }^{15}$. Atypical EEG findings could be associated with the absence of myoclonic jerks.

The major misleading finding probably was the absence of myoclonic jerks during the fully developed disease. Even though the series of immunosuppressive treatments had questionable effect on the course of the disease, they manifestly affected the diagnosis. We believe that the use of TPE resulted in false-negative serology for measles and postponed the opportunity to make an accurate diagnosis. This was supported by seroconversion in this patient with advanced disease in the weeks following TPE. Since immunosuppressants commonly and logically aggravated the course of the disease, transitory improvement noted after the first steroid pulse treatment was quite unusual. The prolonged indolent course of the disease followed by accelerated and aggressive phase in the reported patient was expected due to his old age $\mathrm{e}^{1,16}$.

In conclusion, we would like to highlight several points. First, despite the fact that SSPE is almost exclusively a disease of childhood, it can occur in adults as well. Second, the diagnosis of adult-onset SSPE can be especially challenging because of atypical clinical presentation and broadened differential diagnosis compared to the pediatric population. Finally, the employment of unnecessary treatments such as plasmapheresis accompanied by the lack of typical EEG findings and myoclonic jerks can result in missing the correct diagnosis due to false-negative serology for measles.

\section{Acknowledgments}

We thank Mrs. Arijana Pavelić and Mrs. Marija Fijucek for their help in preparation of the manuscript.

\section{References}

1. Garg RK. Subacute sclerosing panencephalitis. Postgrad Med J. 2002;78:63-70. doi: 10.1136/pmj.78.916.63.
2. Saha V, John TJ, Mukundan P. High incidence of subacute sclerosing panencephalitis in South India. Epidemiol Infect. 1990;104:151-6. doi: 10.1017/s0950268800054637.

3. Prashanth LK, Taly AB, Sinha S, Ravi V. Subacute sclerosing panencephalitis (SSPE): an insight into the diagnostic errors from a tertiary care university hospital. J Child Neurol. 2007; 22(6):683-8. doi: 10.1177/0883073807303999

4. Prashanth LK, Taly AB, Ravi V, Sinha S, Arunodaya GR. Adult onset subacute sclerosing panencephalitis: clinical profile of 39 patients from a tertiary care centre. J Neurol Neurosurg Psychiatry. 2006;77:630-3. doi: 10.1136/jnnp.2005.085829

5. Sharma P, Singh D, Singh MK, Garg RK, Kohli N. Brainstem involvement in subacute sclerosing panencephalitis. Neurol India. 2011;59:273-5. doi: 10.4103/0028-3886.79146.

6. Schiffmann R, Van der Knaap MS. An MRI-based approach to the diagnosis of white matter disorders. Neurology. 2009;72: 750-9. doi: 10.1212/01.wnl.0000343049.00540.c8

7. Gutierrez J, Issacson RS, Koppel BS. Subacute sclerosing panencephalitis: an update. Dev Med Child Neurol. 2010;52 (10):901-7. doi: 10.1111/j.1469-8749.2010.03717.x

8. Przybek J, Gniatkowska I, Mirowska-Guzel D, Członkowska A. Evolution of diagnostic criteria for multiple sclerosis. Neurol Neurochir Pol. 2015;49(5):313-21. doi: 10.1016/j.pjnns.2015. 07.006.

9. Brecht I, Weissbrich B, Braun J, Toyka KV, Weishaupt A, Buttmann M.Intrathecal, polyspecific antiviral immune response in oligoclonal band negative multiple sclerosis. PLoS ONE 2012;7(7):e40431. doi: 10.1371/journal.pone.0040431.

10. Samlıŏlu P, Unalp A, Gökçay A, Altuğlu I, Oztürk A, Zeytinoğlu A. Subacute sclerosing panencephalitis cases diagnosed by increased CSF/serum measles antibody indices. Mikrobiyol Bul. 2012;46:716-8.

11. Green SH, Wirtschafter J. Ophthalmoscopic findings in subacute sclerosing panencephalitis. Br J Ophthalmol. 1973;57: 780-7. doi: 10.1136/bjo.57.10.780.

12. Caruso JM, Robbins-Tien D, Brown WD, Antony JH, Gascon GG. Atypical chorioretinitis as an early presentation of subacute sclerosing panencephalitis. J Pediatr Ophthalmol Strabismus. 2000;37(2):119-22.

13. Datta SS, Jacob R, Kumar S, Jeyabalan S. A case of subacute sclerosing panencephalitis presenting as depression. Acta Neuropsychiatr. 2006;18:55-7. doi: 10.1111/j.0924-2708.2006. 00117.x.

14. Prashanth LK, Taly AB, Ravi V, Sinha S, Rao S. Long term survival in subacute sclerosing panencephalitis: an enigma. Brain Dev. 2006;28(7):447-52. doi: 10.1016/j.braindev.2006. 01.008

15. Markand ON, Panszi JG. The electroencephalogram in subacute sclerosing panencephalitis. Arch Neurol. 1975;32:71926. doi: 10.1001/archneur.1975.00490530041002.

16. Gagnon A, Bouchard RW. Fulminating adult-onset subacute sclerosing panencephalitis in a 49-year-old man. Arch Neurol. 2003;60(8):1160-1. doi: 10.1001/archneur.60.8.1160. 
Sažetak

\section{ATIPIČNI SLUČAJ SUBAKUTNOG SKLEROZIRAJUĆEG PANENCEFALITISA U ODRASLOG BOLESNIKA}

L. Stemberger Maric, O. Đaković Rode, K. Viškovic, H. Hećimovic, S. Lambaša i D. Lepur

U ovom radu prikazujemo atipični slučaj subakutnog sklerozirajućeg panencefalitisa u odraslog bolesnika koji se prezentirao nalik multiploj sklerozi. Bolest je bila obilježena dugotrajnim i podmuklim tijekom s naknadnim razvojem brzo progresivne faze uz atipičan EEG nalaz i izostanak mioklonizama. U raspravi se analiziraju teškoće u interpretaciji dijagnostičkih testova, kao i nepovoljan utjecaj terapijskih postupaka u postavljanju definitivne dijagnoze.

Ključne riječi: Odrasle osobe; MRZ (morbili, rubeola, varicela-zoster) reakcija; Multipla skleroza; Subakutni sklerozirajući panencefalitis 